\title{
PENANGANAN DAN PENEGAKAN HUKUM TERKAIT PEMILIHAN KEPALA DAERAH SECARA LANGSUNG DI KABUPATEN BULELENG
}

\author{
Ketut Sudiatmaka \\ Dewa Gede Sudika Mangku
}

\author{
Fakultas Hukum dan Ilmu Sosial \\ Universitas Pendidikan Ganesha \\ Email : sudiatmaka@undiksha.ac.id \\ dewamangku.undiksha@gmail.com
}

\begin{abstract}
Abstrak
Penelitian ini bertujuan untuk menganalisis faktor-faktor penyebab terjadinya kecurangan atau pelanggaran dalam pelaksanaan pemilihan kepada daerah di kabupaten buleleng. Selain itu, mengkaji mengenai dampak pemilihan kepala daerah secara langsung terkait dengan penyelenggaraan pemerintahan daerah di kabupaten Buleleng. Selanjutnya, menganalisis mengenai proses penanganan dan penegakan hukum terkait pemilihan kepala daerah secara langsung di kabupaten Buleleng. Penelitian ini menggunakan metode penelitian hukum empiris dengan menggunakan data primer dan tambahan data sekunder. Hasil penelitian ini menunjukkan bahwa faktor-faktor penyebab terjadinya kecurangan atau pelanggaran dalam adalah karena keinginan dari para calon untuk memenangkan pemilihan, sehingga para calon mengatur strategi dan mencari pihak-pihak yang memiliki andil atau peran yang sangat berpengaruh di tempat-tempat tertentu. Terkait dengan dampak pemilihan kepala daerah secara langsung dalam hal penyelenggaraan pemerintahan daerah adalah adanya larangan untuk ikut kampanye diluar cuti, dilarang menggunakan fasilitas-fasilitas milik negara, dilarang melakukan surat menyurat yang mengatasnamakan pemerintah daerah untuk tujuan kampanye dan menekan bawahan terkait dengan pemilu. Selanjutnya terkait proses penanganan dan penegakan hukum terkait pelanggaran pemilihan kepala daerah tergantung dari jenis pelanggarannya, sehingga kepolisian, KPU, Bawaslu, dan PTTUN memiliki peran dalam penyelesaian sengketa pemilihan kepala daerah.
\end{abstract}

Kata Kunci: Penanganan dan Penegakan Hukum, Pemilihan Kepala Daerah, Komisi Pemilihan Umum

\section{Abstract}

This study aims to analyze the factors causing fraud or violations in the implementation of elections to regions in Buleleng. In addition, reviewing the impact of regional head elections is directly related to the implementation of regional governance in Buleleng. Furthermore, analyzing the process of handling and law enforcement related to direct regional elections in Buleleng. This study uses empirical le gal research methods using primary data and additional secondary data. The results of this study indicate that the factors that cause fraud or internal violations are due to the desire of candidates to win the election, so that candidates organize strategies and look for parties who have a very influential role in certain places. Related to the impact of direct regional elections in terms of the administration of local government is the prohibition to participate in campaigns outside of leave, prohibited from using state-owned facilities, prohibited from doing correspondence on behalf of local governments for the purpose of campaigning and suppressing subordinates related to the election. 
Furthermore, related to the handling process and law enforcement related to violations of regional head elections depending on the type of violation, so that the police, KPU, Bawaslu, and PTTUN have a role in resolving disputes over regional head elections.

Keywords: Handling and Enforcement Law, Election of Regional Heads, General Election Commission

\section{Pendahuluan}

Negara-negara modern dalam kaitannya sebagai negara kesejahteraan atau welfare state, selalu menyatakan bahwa negaranya menganut sistem demokrasi. Sistem demokrasi di Indonesia telah lahir sejak Indonesia merdeka dan menjadikan aturan dasar dalam penyelenggaraan pemerintahannya, hal ini secara nyata dapat dilihat dalam Pasal 1 ayat (2) Undang-Undang Dasar Negara Republik Indonesia tahun 1945 yang menegaskan kedaulatan berada di tangan rakyat dan dilaksanakan berdasarkan Undang-Undang Dasar. Pasca reformasi dengan telah diamandemenya Undang-Undang Dasar Negara Republik Indonesia 1945 oleh Majelis Permusyawaratan Rakyat (MPR), maka pada tahun 2004 Indonesia memilih Presiden dan anggota legislatif yang dilakukan secara langsung dan kemudian diikuti dengan pemilihan kepala daerah atau pilkada secara langsung dengan landasan hukum yaitu Undang-Undang Nomor 32 Tahun 2004 tentang Pemerintahan Daerah.

Hal tersebut juga tidak terlepas dari adanya penyempurnaan Pasal 18 UUD 1945 pada amandemen kedua tahun 2000. Dalam proses pembahasan Pasal 18 khususnya ayat (4) UUD 1945, MPR sepakat membuka ruang kebebasan bagi daerah dalam proses pemilihan kepala daerah. Menurut Pasal 18 ayat (4) UUD 1945 menyatakan bahwa Gubernur, Bupati, dan Walikota masing-masing sebagai kepala pemerintah daerah provinsi, kabupaten, dan kota dipilih secara demokratis.
Namun dipilih secara demokratis tersebut bersifat luwes, sehingga mencakup pengertian pemilihan kepala daerah secara langsung ataupun pemilihan kepala daerah secara tidak langsung yang dilakukan oleh DPRD (Asshiddiqie, 2002:22). Salah satunya wujud dari demokratisasi itu adalah dilaksanakannya pemilihan kepala daerah secara langsung (Azis, 2011:9).

Kepala daerah dan wakil kepala daerah dipilih dalam satu pasangan calon yang dilaksanakan secara demokratis berdasarkan asas langsung, umum, bebas, rahasia, jujur, dan adil (Pasal 56 ayat (1) Undang-Undang Dasar Negara Republik Indonesia Tahun 1945.). Selanjutnya, Pasangan calon sebagaimana dimaksud diajukan oleh partai politik atau gabungan partai politik (Pasal 56 ayat (2) UndangUndang Dasar Negara Republik Indonesia Tahun 1945.). Selain itu, dengan disahkannya Undang-Undang Republik Indonesia Nomor 32 Tahun 2004 tentang Pemerintahan Daerah sebagaimana telah dirubah dengan Undang-Undang Republik Indonesia Nomor 8 Tahun 2005, Undang-Undang Republik Indonesia Nomor 12 Tahun 2008, Undang-Undang Republik Indonesia Nomor 23 Tahun 2014, dan terakhir Undang-Undang Republik Indonesia Nomor 9 Tahun 2015 Tentang Pemerintahan Daerah, menentukan bahwa pemilihan kepala daerah dilakukan secara langsung oleh rakyat daerah. Hal ini sering dipandang sebagai sebuah titik balik bagi praktek demokrasi di Indonesia, karena untuk pertama kalinya, masyarakat luas 
dilibatkan secara langsung untuk memilih pemimpinnya.

Peraturan pemerintah nomor 6 Tahun 2005 tentang Pemilihan, Pengesahan, Pengangkatan dan Pemberhentian Kepala Daerah dan Wakil Kepala Daerah juga menegaskan bahwa parpol atau gabungan parpol sebelum menetapkan calon wajib membuka kesempatan yang seluasluasnya bagi calon perseorangan. Peraturan Pemerintah Nomor 6 Tahun 2005 juga menjelaskan bahwa proses penyaringan calon kepala daerah dilakukan secara demokratis dan transparan sesuai dengan mekanisme internal parpol. Bahkan, dalam proses penetapan calon, partai politik wajib memperhatikan pendapat dan tanggapan masyarakat. Hal tersebut diberlakukan agar pelaksanaan pemilihan kepala daerah dapat berlangsung secara demokratis dan transparan (Prihatmoko, 2005:243-244).

Perubahan sistem pemilihan kepala daerah dari dipilih oleh anggota DPRD menjadi dipilih oleh rakyat merupakan salah satu usaha pemberdayaan masyarakat dalam bidang pemerintahan juga menjadi tuntutan dalam agenda reformasi. Alasan pentingnya pemilihan kepala daerah dilakukan secara langsung adalah untuk membangun otonomi daerah, menumbuhkan kepemimpinan lokal, meningkatkan akuntabilitas publik dan transparansi pemerintah, serta sebagai proses legitimasi rakyat yang kuat (Simamora, 2011:229). Hal tersebut juga merupakan konsekuensi dari tuntutan demokratisasi yang tentunya akan berpengaruh pada kegiatan pemerintahan di tingkat lokal (Sarundajang, 2005:23). Selanjutnya, pemilihan kepala daerah secara langsung memberikan kesempatan kepada rakyat di daerah yang bersangkutan untuk memilih pimpinan daerahnya sesuai dengan aspirasinya. Kepala Daerah setidaknya mempunyai tanggung jawab moral terhadap rakyatnya.

Sejak bulan Juni 2005 telah berlangsung pemilihan kepala daerah di lebih dari 200 daerah Kabupaten, Kota, dan Provinsi di Indonesia. Namun pemilihan kepala daerah yang berlangsung mulai bulan Juni 2005 justru dipenuhi dengan berbagai problematika seperti adanya konflik horizontal, politik uang, dan sikap tidak menerima kekalahan (Mahfud, 2006:247). Dalam pelaksanaannya, Pemilihan kepala daerah yang dilakukan secara langsung tidak berjalan sesuai dengan harapan banyak kalangan sehingga menimbulkan kecemasan bagi beberapa pihak. Hal ini dipicu oleh munculnya berbagai konflik yang cukup besar sehingga mewarnai perjalanan Pemilihan kepala daerah secara langsung yang dilaksanakan di beberapa daerah. Banyak terjadi penyimpangan di berbagai daerah terkait degan pemilihan kepala daerah mulai dari pertikaian antar pendukung, perusakan fasilitas publik, perusakan gedung-gedung milik pemerintah yang tak terhitung jumlahnya. Selain itu beberapa calon kepala daerah melakukan perbuatan curang seperti memanipulasi prasyarat formal, melakukan tindakan-tindakan yang kurang terpuji dengan menghalalkan segala cara agar dapat terpilih dan atau melakukan tindakan yang melanggar ketentuan dalam pelaksanaan pemilihan kepala daerah (Aribowo, 1996:5).

Hal tersebut sebagaimana yang terjadi dalam pemilihan kepala daerah di kabupaten Buleleng. Terkait dengan proses pemilihan kepala daerah di kabupaten Buleleng, terungkapnya sejumlah persoalan atau aduan dari bakal pasangan calon (paslon) Bupati/Wakil Bupati Buleleng dari jalur 
perseorangan terkait dugaan pelanggaran kode etik yang dilakukan penyelenggara pemilihan umum (Pemilu) pada persidangan kode etik DKPP dan Tim Pemeriksa Daerah (TPD) di Gedung Pertemuan Kantor Sekretariat KPU Provinsi Bali (http://katabali.com/2016/12/kasuspilkada-buleleng-bisa-dipakai-evaluasibagi-pembuat-uu-untuk-persiapanpilkada-2018/).

Kasus selanjutnya adalah dengan munculnya berita kecurangan di salah satu tempat pemungutan suara (TPS). Terkait dugaan adanya kecurangan, berita yang dihimpun dari berbagai sumber mengatakan bahwa oknum KPPS di TPS III desa Kalibukbuk melakukan pencoblosam lebih dari sekali. Untuk mengklarifikasi persoalan ini Panwalsih telah mengundang enam orang yang berkaitan dengan kasus tersebut. Dari enam pihak yang telah diklarifikasi tersebut, panwaslih belum juga menemukan apakah dugaan mencoblos lebih dari satu kali itu memenuhi unsur pelanggaran pidana pemilu atau tidak (http://untukbali.com/berita/politik/86menggali-kecurangan-di-pilkadabuleleng).

Kasus dugaan kecurangan pencoblosan pilkada buleleng 2017 di TPS 3 Desa Kalibukbuk, ditindaklanjuti oleh Sentra Penegakan Hukum Terpadu Pilkada Buleleng 2017. Setelah sebelumnya memanggil beberapa saksi, Sentra Penegakan Hukum Terpadu kembali mendatangkan tiga orang saksi pelapor yang diduga melihat kasus yang terjadi di TPS 3 Kalibukbuk. Ketua Sentra Penegakan Hukum Terpadu Pilkada Buleleng yang juga Komisioner Panwaslih Buleleng, saat dikonfirmasi usai melakukan klarifikasi terhadap tiga saksi menyatakan berdasarkan keterangan pelapor bahwa ia mencurigai namun tidak melihat oknum penyelenggara di TPS 3 Desa Kalibukbuk melakukan pencoblosan (http://rri.co.id/singaraja/post/berita/362 528/pilkada_buleleng_2017/tiga_saksi_ kasus_tps_3_kalibukbuk_buleleng_dipe riksa.html).

Perkembangan terkait dengan Kasus dugaan pencoblosan 2 kali di TPS 3 Desa Kalibukbuk Kecamatan Buleleng yang dilakukan anggota KPPS setempat tidak memenuhi unsur pelanggaran pidana pemilu. Setelah melakukan pemeriksaan 12 orang saksi pelapor yang ditangani Sentra Penegakan Hukum Terpadu Kabupaten Buleleng, terkait dugaan pelanggaran tindak pidana pilkada di TPS 3 Desa Kalibukbuk, ternyata tidak memenuhi unsur pelanggaran pidana pemilu. Terkait dugaan pelanggaran pilkada yang dilakukan 2 orang anggota KPPS di TPS 3 Desa Kalibukbuk, Ketua Panwaslih Buleleng setelah melakukan rapat pleno hasil pemeriksaan yang dilakukan Sentra Penegakan Hukum Terpadu, Panwaslih Kabupaten Buleleng serta Panwas Kecamatan Buleleng menyimpulkan, laporan yang dilayangkan ke panwaslih tidak memenuhi syarat untuk ditindak lanjuti.

Pelanggaran yang terjadi di TPS 3

Desa Kalibukbuk hanya merupakan pelanggaran administrasi dan sudah dilakukan pemilihan suara ulang (PSU). Untuk laporan No 002/LB/Pilkada/02/2017 tertanggal 15 Pebruari 2017, status laporan tersebut tidak memenuhi syarat untuk ditindak lanjuti, karena tidak memenuhi unsurunsur melanggar Pasal 178 huruf $b$ UU RI No 10 tahun 2016, sehingga tidak dapat ditindaklanjuti. Sementara itu, Ketua Sentra Penegakan Hukum Terpadu mengungkapkan, dalam kasus dugaan pelanggaran pilkada di TPS 3 Kalibukbuk, yang bersangkutan hanya melakukan kesalahan tempat mencoblos (http://www.rri.co.id/singaraja/post/beri 
ta/363165/pilkada_buleleng_2017/panw aslih_buleleng_putuskan_kasus_tps_3_ kalibukbuk_tidak_memenuhi_unsur_pid ana.html).

Melihat permasalahanpermasalahan yang terjadi terkait dengan pemilihan kepala daerah secara langsung sebagaimana yang telah dipaparkan, maka penulis tertarik untuk menganalisa lebih dalam mengenai bentuk penegakan hukum terkait dengan pemilihan kepala daerah serta dampak yang ditimbulkan dengan adanya proses pemilihan kepala daerah secara langsung. Selanjutnya penulis memberikan judul dalam penelitian ini yaitu "Penanganan Dan Penegakan Hukum Terkait Pemilihan Kepala Daerah Secara Langsung Di Kabupaten Buleleng”.

\section{Rumusan Masalah}

Berdasarkan latar belakang yang telah diuraikan di atas, penulis mengangkat dua permasalahan yang meliputi:

1. Bagaimana dampak pemilihan kepala daerah secara langsung terkait dengan penyelenggaraan pemerintahan daerah di kabupaten Buleleng?

2. Bagaimana proses penanganan dan penegakan hukum terkait pelanggaran pemilihan kepala daerah secara langsung di kabupaten Buleleng?

\section{Tujuan Penelitian}

Tujuan yang ingin dicapai oleh penulis dari penelitian ini adalah:

1. Mengkaji faktor-faktor penyebab terjadinya kecurangan atau pelanggaran dalam pelaksanaan pemilihan kepada daerah di kabupaten buleleng

2. Mengkaji mengenai dampak pemilihan kepala daerah secara langsung terkait dengan penyelenggaraan pemerintahan daerah di kabupaten Buleleng.

3. Menganalisis mengenai proses penanganan dan penegakan hukum terkait pemilihan kepala daerah secara langsung di kabupaten Buleleng.

\section{Manfaat Penelitian}

Dalam penulisan penelitian ini, diharapkan terdapat manfaat yang dapat diambil. Manfaat penelitian meliputi manfaat teoretis dan manfaat praktis. Penjelasan daripada manfaat tersebut adalah sebagai berikut.

\section{Manfaat Teoretis}

Penelitian ini diharapkan dapat menambah keterampilan menulis bagi peneliti, menambah pengetahuan hukum terkait dengan penyelesaian sengketa pemilihan kepala daerah, sumbangan pemikiran dalam pemecahan suatu masalah hukum, acuan pengambilan keputusan yuridis bagi peneliti terkait dengan kasus-kasus pemilihan kepala daerah secara langsung, dan penguatan konsep-konsep hukum terkait dengan penanganan dan penegakan hukum terkait pemilihan kepala daerah secara langsung di kabupaten Buleleng.

\section{Manfaat Praktis}

Penelitian ini diharapkan dapat bermanfaat dan memberikan masukan kepada Pemerintah Daerah Kabupaten Buleleng, Komisi Pemilihan Umum Daerah, dan masyarakat untuk dapat mengatasi dampak-dampak negatif dari adanya pemilihan kepala daerah secara langsung dan dapat membuat kebijakankebijakan yang dapat mengurangi atau bahkan meniadakan sengketa-sengketa terkait dengan pemilihan kepala daerah serta penanganan dan penegakan hukum terkait pemilihan kepala daerah secara langsung di kabupaten buleleng. 


\section{Metode Penelitian}

Penelitian mengenai "Penanganan dan Penegakan Hukum Terkait Pemilihan Kepala Daerah Secara Langsung Di Kabupaten Buleleng" adalah merupakan jenis penelitian ilmu hukum dengan kajian empiris. Karena penelitian ini menyangkut data maka dengan sendirinya merupakan penelitian hukum empiris (M. Hadjon, 2005:5). Penelitian ini menggunakan data primer dengan tambahan data sekunder. Data primer dikumpulkan melalui observasi dan wawancara. Terkait dengan tambahan data sekunder, data tersebut dikumpulkan melalui studi pustaka/dokumen. Teknik penentuan sampel penelitian menggunakan non probability sampling dengan teknik pengolahan dan analisis data yang dilakukan secara kualitatif.

\section{Hasil dan Pembahasan \\ Dampak Pemilihan Kepala Daerah Secara Langsung terkait dengan Penyelenggaraan Pemerintahan Daerah di Kabupaten Buleleng.}

Berbagai pelanggaran yang terjadi disebabkan oleh berbagai faktor yang dapat mempengaruhi pilkada yang tidak demokratis seperti penyelenggara pemilu yang tidak profesional, adanya oknum yang menggunakan sisa surat suara untuk dicoblos bagi pasangan kandidat tertentu, indikasi politik uang, serta politisasi birokrasi untuk memenangkan pasangan tertentu. Berdasarkan hasil wawancara dengan Bapak Putu Aswina sebagai Sekretaris KPU Kabupaten Buleleng, faktor-faktor penyebab terjadinya kecurangan dalam pemilihan umum adalah karena keinginan dari para calon untuk memenangkan pemilihan, sehingga para calon mengatur strategi dan mencari pihak-pihak yang memiliki andil atau peran yang sangat berpengaruh di tempat-tempat tertentu. Para calon mengetahui data-data jumlah pemilih di masing-masing tempat, sehingga tujuan mereka untuk mendapatkan suara dilakukan dengan cara kampanye, money politik, intimidasi, dan lain sebagainya. Terkait dengan hal-hal yang dilakukan tersebut kadangkala susah untuk dibuktikan.

Pemilihan kepala daerah secara langsung memberikan suatu hak politik yang tegas bagi masyarakat yang ada di daerah, sehingga semua elemen masyarakat dapat menjalankan hak politiknya. Pada sistem kedaulatan rakyat, kekuasaan tertinggi berada di tangan rakyat yang pada hakikatnya berasal dari rakyat, untuk rakyat, dan dikelola oleh rakyat. Demokrasi tidak hanya terkait dengan pelembagaan gagasan-gagasan luhur tentang kehidupan bernegara yang ideal, tetapi juga merupakan persoalan tradisi dan budaya politik yang egaliter dalam realitas pergaulan hidup yang berkeragaman dan menghargai perbedaan (Jimly, 2010: 58).

Pemilihan kepala daerah yang dilakukan secara langsung memiliki dampak positif yang dapat dilihat dari sisi demokrasi, pemilihan kepala daerah secara langsung sudah menunjukkan nuansa demokrasi yang sesungguhnya. Kehidupan politik yang demokratis di daerah secara bertahap dan berkesinambungan dapat dibangun apabila dalam pelaksanaannya berjalan dengan jujur dan sukses. Keterlibatan rakyat secara langsung dalam memilih dan menentukan seorang kepala daerah sejalan dengan hakekat dari demokrasi yang menekankan pada pemerintahan yang berasal dari rakyat, oleh rakyat dan untuk rakyat. Daya kritis yang dimiliki oleh masyarakat akan semakin meningkat karena memiliki andil di dalam menetukan pemimpinya sendiri.

Melalui pemilihan kepala daerah secara langsung, suara rakyat menjadi 
sangat berharga sehingga kepentingan rakyat memperoleh perhatian yang lebih besar oleh siapapun yang berkeinginan mencalonkan diri sebagai kepala daerah. Kepercayaan masyarakat akan meningkat, karena prinsip kedaulatan dapat terwujudkan secara faktual. Sehingga partisipasi akan lebih mudah digalang. Hal tersebut tentunya berkaitan dengan kedudukan dan legitimasi yang dimiliki oleh seorang kepala daerah yang terpilih. Kepala daerah yang terpilih akan memiliki legitimasi yang tinggi dari masyarakat dan mempunyai kepedulian terhadap persoalan masyarakat. Seorang kepala daerah untuk memenangkan pertarungan pemilihan haruslah menguasai dan menyenangkan hati rakyat, hal tersebut tentunya berbeda dengan pemilihan tidak langsung yang hanya tergantung pada anggota DPRD bukan pada rakyat. Kemudian, seorang kepala daerah terpilih juga mampunyai kedudukan yang sejajar dengan anggota DPRD yaitu sama-sama dipilih langsung oleh rakyat, sehingga terciptnya check and balances antara kepala daerah dengan DPRD.

Pemilihan kepala daerah yang dilakukan secara langsung menjadikan proses lebih partisipasi karena membuka akses dan kontrol masyarakat sebagai pihak yang terlibat dalam pemilukada. Hal tersebut menjadi prakondisi untuk mewujudkan kedaulatan ditangan rakyat dalam hal perpolitikan dan pemerintahan. Proses pemilukada secara langsung memberikan ruang dan pilihan yang terbuka bagi masyarakat untuk menentukan calon pemimpin yang memiliki kapasitas, komitmen dan legitimasi dimata masyarakat sehingga pemimpin yang baru tersebut mendapat dukungan dan kepercayaan dari masyarakat yang menimbulkan rasa tanggung jawab secara timbal balik.
Pemilihan kepala daerah yang dilakukan secara langsung juga memberikan dampak negatif yang cukup besar dalam melakukan penyelenggaraan pemerintahan di daerah. Hal tersebut terkait dengan tidak efektif dan efesiennya anggaran belanja dan penyelenggaraan pemilihan kepala daerah. Kadangkala dana APBD yang tersedia dan digunakan untuk mewujudkan kesejahteraan rakyat justru digunakan untuk pemilihan kepala daerah, sehingga terdapat pengurangan dana bagi kesejahteraan rakyat. Rakyat juga tidak akan percaya pada pemerintahan, apabila dalam pelaksanaannya tidak fair, tidak benar, tidak jujur dan bahkan penuh kecurangan. Sehingga menimbulkan sikap saling curiga, tidak percaya, bahkan konflik antar pendukung.

Hubungan emosional yang kuat antara calon kepala daerah dan wakilnya akan memudahkan terjadinya konflik horisontal antar pendukung karena faktor primordial. Kampanye negatif yang menyerang pribadi akan mengubah kompetisi perebutan jabatan kepala daerah dan wakilanya menjadi konflik yang terbuka. Apabila birokrasi bersifat tidak netral, maka akan terjadi politisasi birokrasi akan membuat iklim dan budaya organisasi menjadi tidak sehat karena akan terbentuk kelompokkelompok yang berafiliasi pada partai politik tertentu. Hal lainnya adalah terkait dengan penyelenggaraan pemilihan kepala daerah yang tidak serentak dalam satu provinsi sehingga tidaklah efektif dan efisien karena menghabiskan banyak waktu dalam penyelenggaraan pemerintahan, sehingga waktu yang ada untuk memberikan kesejahteraan kepada rakyat justru digunakan untuk mengurus pemilihan kepala daerah.

Berdasarkan hasil wawancara dengan Bapak Putu Aswina sebagai 
Sekretaris KPU Kabupaten Buleleng, beliau menjelaskan bahwa Pilkada memberikan dampak terhadap penyelenggaran pemerintahan seperti terdapatnya peraturan bahwa pemerintah daerah dilarang untuk melakukan mutasi enam bulan sebelum pilkada berlangsung. Selain itu, dilarang untuk ikut kampanye diluar cuti, dilarang menggunakan fasilitas-fasilitas milik negara seperti rumah dinas, telefon, televisi milik negara untuk kepentingan kampanye, kecuali yang melekat pada diri pejabat misalnya seperti pengamanan atau protokoler. Selanjutnya dilarang untuk melakukan surat menyurat yang mengatasnamakan pemerintah daerah untuk tujuan kampanye dan menggunakan kewenangannya untuk menekan bawahan terkait dengan pemilu.

\section{Proses penanganan dan penegakan hukum terkait pemilihan kepala daerah secara langsung di kabupaten Buleleng.}

Penanganan dan penegakkan hukum merupakan usaha dalam rangka menanggulangi kejahatan secara rasional untuk memenuhi keadilan dan berdaya guna. Dalam rangka menanggulangi kejahatan terhadap berbagai sarana sebagai reaksi yang dapat diberikan kepada pelaku kejahatan, berupa sarana pidana maupun non hukum pidana. Pilar dalam sistem demokrasi adalah adanya mekanisme penyaluran pendapat rakyat secara berkala dan berkesinambungan melalui pemilihan umum sebagai sebuah mekanisme politik untuk mengartikulasikan aspirasi dan kepentingan warga negara dalam proses memilih sebagian rakyat menjadi pemimpin pemerintah (Paimin, 2004: 71).

Penggunaan pidana dalam proses pemilu merupakan hal yang tidak mudah karena pengawas pemilu, penyidik Polri, Jaksa dan Hakim memiliki persepsi yang berbeda terhadap beberapa bentuk kasus pidana Pemilu. Alur Penanganan Pelanggaran Pemilu Berdasarkan Perbawaslu Nomor 14 Tahun 2012 mengenai penanganan tindak pidana dalam sistem peradilan pidana pemilu tidaklah sederhana. Sistem penanganan tindak pidana pemilu jauh lebih rumit dibandingkan tindak pidana biasa yang hanya melibatkan Polisi, Jaksa dan Pengadilan. Sementara tindak pidana pemilu juga melibatkan pengawas pemilu. Sehingga, kondisi inipun dinilai sebagai salah satu alasan kenapa penanganan tindak pidana pemilu menjadi tidak efektif.

Berdasarkan hasil wawancara dengan Bapak Putu Aswina sebagai Sekretaris KPU Kabupaten Buleleng, beliau menjelaskan bahwa proses penanganan dan penegakan hukum terkait pelanggaran pemilihan kepala daerah secara langsung di Kabupaten Buleleng tergantung dari jenis pelanggarannya. Apabila terjadi pelanggaran seperti adanya banyak ancaman dan tindakan intimidasi, maka hal tersebut termasuk dalam suatu tindak pidana pemilu. Hal tersebut tentunya menjadi kewenangan pihak kepolisian untuk melakukan proses secara hukum. Jikalau terjadi suatu kasus seperti KPU yang memberikan keputusan bahwa beberapa calon tidak di loloskan karena suatu hal, maka kasus tersebut akan di bawa ke Bawaslu dan hal tersebut termasuk dalam suatu sengketa proses. Hal yang menjadi sengketa adalah terkait dengan keputusan KPU. Bawaslu nantinya akan mencabut keputusan KPU tersebut dan melakukan verifikasi ulang ke daerahdaerah. Setelah Bawaslu melakukan verifikasi ulang, nantinya KPU akan membuat keputusan berdasarkan hasil 
verifikasi Bawaslu. Keputusan Bawaslu tersebutlah yang nantinya dibawa ke Pengadilan Tinggi Tata Usaha Negara (PTTUN). PTTUN kemudian akan membuat keputusan yang mencabut keputusan KPU dan nantinya KPU kemudian membuat keputusan dengan berdasarkan kepada putusan dari PTTUN terkait dengan lolos atau tidaknya orang yang mencalonkan diri dalam pemilu.

\section{Penutup}

\section{Simpulan}

1. Dampak pemilihan kepala daerah secara langsung terkait dengan penyelenggaraan pemerintahan daerah adalah adanya larangan untuk ikut kampanye diluar cuti, dilarang menggunakan fasilitasfasilitas milik negara seperti rumah dinas, telefon, televisi milik negara untuk kepentingan kampanye, kecuali yang melekat pada diri pejabat, dilarang melakukan surat menyurat yang mengatasnamakan pemerintah daerah untuk tujuan kampanye dan menekan bawahan terkait dengan pemilu. Selain itu pemilihan kepala daerah yang dilakukan secara langsung memiliki dampak positif yang dapat dilihat dari sisi demokrasi. Melalui pemilihan kepala daerah secara langsung, suara rakyat menjadi sangat berharga sehingga kepentingan rakyat memperoleh perhatian yang lebih besar oleh siapapun yang berkeinginan mencalonkan diri sebagai kepala daerah. Sedangkan mengenai dampak negatif terkait dengan tidak efektif dan efesiennya anggaran belanja yang kadangkala menggunakan dana APBD untuk pemilihan kepala daerah, sehingga terdapat pengurangan dana bagi kesejahteraan rakyat.

2. Proses penanganan dan penegakan hukum terkait pelanggaran pemilihan kepala daerah secara langsung di Kabupaten Buleleng tergantung dari jenis pelanggarannya. Apabila terjadi pelanggaran seperti adanya banyak ancaman dan tindakan intimidasi, maka hal tersebut termasuk dalam suatu tindak pidana pemilu. Hal tersebut tentunya menjadi kewenangan pihak kepolisian untuk melakukan proses secara hukum. Jikalau terjadi suatu kasus seperti KPU yang memberikan keputusan bahwa beberapa calon tidak di loloskan karena suatu hal, maka kasus tersebut akan di bawa ke Bawaslu dan membutuhkan putusan dari PTTUN.

\section{Saran}

1. Pencegahan terhadap kecurangan atau pelanggaran dalam pelaksanaan pemilihan kepala daerah di Kabupaten Buleleng perlu dilakukan dengan cara melakukan pemilihan secara transparan dan terbuka. Para pihak harus menyelenggarakan pemilihan secara profesional dengan menghindari atau tidak melakukan politik uang, politisasi birokrasi, intimidasi, dan lain sebagainya yang mengarah pada pelanggaran terhadap peraturanperaturan terkait dengan pemilihan umum.

2. Pemilihan kepala daerah yang dilakukan secara langsung harus memperhatikan APBD agar penggunaannya tetap efektif dan efisien yang bertujuan untuk mewujudkan kesejahteraan rakyat. Penggunaan APBD untuk penyelenggaraan pemilihan 
kepala daerah perlu untuk dikaji ulang agar peruntukan yang ada tidak menyalahi aturan.

3. Para pihak yang terlibat dalam sengketa pemilihan kepala daerah harus memperhatikan aturan hukum dan proses penyelesaian sengketa yang berlaku agar sengketa dapat segera terselesaikan dan tidak menimbulkan konflik yang bekepanjangan diantara masingmasing pihak yang terlibat dalam pemilihan.

\section{Daftar Pustaka \\ Buku}

Asshiddiqie, 2002, Konsolidasi Naskah UUD 1945 setelah perubahan keempat, Pusat Studi Hukum Tata Negara Fakultas Hukum Universitas Indonesia, Depok.

Asshiddiqie Jimly, 2010, Konstitusi dan Konstitusionalisme Indonesia, Sinar Grafika, Jakarta.

Azis, M. Noor, 2011, Pengkajian Hukum Tentang Pemilihan Kepala Daerah, Badan Hukum Pembinaan Hukum Nasional, Jakarta.

Aribowo, dkk, 1996, Mendemokratiskan Pemilu, ELSAM, Jakarta.

MD, Mahfud, 2006, Membangun Politik Hukum, Menegakkan Konstitusi, Pustaka LP3ES, Jakarta.

Napitupulu Paimin, 2004, Peran dan Pertanggungjawaban DPR Kajian di DPRD Provinsi DKI Jakarta, Disertasi, Alumni, Bandung.

Sarundajang, S.H., 2005, Pilkada Langsung, Problema dan Prospek, Kata Hasta Pustaka, Jakarta.
Prihatmoko, Joko J., 2005, Pemilihan Kepala Daerah Langsung, Filosofi, system dan problematika Penerapan di Indonesia, Pustaka bersama LP3M Universitas Wahid Hasyim.

Simamora, Janpatar, Eksistensi Pemilukada Dalam Rangka Mewujudkan Pemerintahan Daerah Yang Demokratis, Jurnal Mimbar Hukum, Vol. 23 No. 1, Februari 2011, Yogyakarta: Fakultas Hukum UGM.

\section{Instrumen Hukum}

Undang-Undang Dasar Negara Republik Indonesia Tahun 1945.

Undang-Undang Republik Indonesia Nomor 9 Tahun 2015 tentang Pemerintahan Daerah.

Undang-Undang Nomor 22 Tahun 2014 tentang Pemilihan Gubernur, Bupati, dan Walikota yang mengatur khusus mengenai pemilihan kepala daerah.

Undang-Undang No. 1 Tahun 2015 tentang Penetapan Peraturan Pemerintah Pengganti UndangUndang No. 1 Tahun 2014 tentang Pemilihan Gubernur, Bupati, dan Walikota menjadi Undang-Undang.

Undang-Undang No. 8 Tahun 2015 tentang Pemilihan Gubernur, Bupati, dan Walikota menjadi Undang-Undang.

Peraturan pemerintah nomor 6 Tahun 2005 tentang Pemilihan, Pengesahan, Pengangkutan dan Pemberhentian Kepala Daerah da Wakil Kepala Daerah.

Peraturan Pemerintah Pengganti Undang-Undang Nomor 1 Tahun 2014 tentang Pemilihan Gubernur, Bupati, Walikota.

\section{Internet}

Katabali, Kasus Pilkada Buleleng Bisa Dipakai Evaluasi, Bagi Pembuat

\section{Jurnal}

UU untuk Persiapan Pilkada 
2018, 1 Desember 2016, URL: http://katabali.com/2016/12/kasus -pilkada-buleleng-bisa-dipakaievaluasi-bagi-pembuat-uu-untukpersiapan-pilkada-2018/, diakses pada tanggal 29 November 2017.

Ketut Sujana, Tiga Saksi Kasus TPS 3 Kalibukbuk Buleleng Diperiksa, 18 Februari 2017, URL: http://rri.co.id/singaraja/post/berit a/362528/pilkada_buleleng_2017/ tiga_saksi_kasus_tps_3_kalibukb uk_buleleng_diperiksa.html, diakses pada tanggal 29 November 2017.

Ketut Sujana, Panwaslih Buleleng Putuskan Kasus TPS 3

November 2017.
Kalibukbuk Tidak Memenuhi Unsur Pidana, 20 February, URL: http://www.rri.co.id/singaraja/post /berita/363165/pilkada_buleleng_ 2017/panwaslih_buleleng_putusk an_kasus_tps_3_kalibukbuk_tidak _memenuhi_unsur_pidana.html, diakses pada tanggal 29 November 2017.

UntukBali.com, Menggali Kecurangan Di Pilkada Buleleng, 21 Februari 2017, URL: http://untukbali.com/berita/politik/ 86-menggali-kecurangan-dipilkada-buleleng, diakses pada tanggal 29 